\title{
Posição de Octavio Mendes no Direito Comercial Brasileiro.
}

\author{
Miguel Reale \\ Catedrático de Filosofia do Direito na \\ Universidade de São Paulo.
}

Não fui aluno de Octávio Mendes, mas, êle foi mestre de energia moral e de dedicação aos valores culturais de quantos, como eu, víamos o velho professor ascender, serenamente, de uma cadeira de rodas à cátedra, a fim de proferir as suas preleções de Direito Comercial.

Fazia-o com desvêlo e, advogado exímio que era, sabia combinar as exigências teóricas com as de ordem prática, tornando os estudantes partícipes de suas dúvidas e convicções, através do exame dos feitos confiados à sua responsabilidade profissional.

Essa preocupação pelas questões práticas, em correlação imediata com os elementos teóricos essenciais, não constituía apenas uma diretriz assumida no âmbito pedagógico, mas representava uma das características de sua obra de jurista.

Quem examina a sua produção científica nota, desde logo, que não o seduziam os amplos debates doutrinários, sendo preferidas as teses necessárias à elucidação dos assuntos que formam o repertório da vida comercial e das questões forenses. Aplica-se-lhe, como uma luva, a apreciação crítica que San Trago Dantas, talvez com excessiva generalização, fêz dos jurisconsultos brasileiros do início da República: "um real conhecimento do direito positivo uma argumentação concisa, livre de prolixidade acadêmica; uma intuição do caso, ainda não falseada pelo gôsto das teorias; 
e uma robusta visão do direito como arte, prevalecendo sôbre a do direito como ciência", ${ }^{1}$

Essas notas distintivas, na obra de Octávio Mendes, revelam-se sobretudo no volume intitulado Ensaios de Direito Comercial, onde se acham reunidas as suas três dissertações de concurso, de 1919, sôbre temas de Direito Mercantil, ${ }^{2}$ e também no seu livro Dos Títulos de Crédito, 1931.

As suas teses de concurso obedecem, em linhas gerais, aos padrões vigentes na época e que, ainda hoje, prevalecem nas provas de seleção de nossos mestres de Direito, mas sem se ater a uma orientação puramente expositiva do pensamento alheio. Não tinha Octávıo Mendes temor de apresentar o resultado de suas pesquisas, fazendo-o até mesmo com veemência.

Analisando-se as suas monografias, o que desde logo se evidencia é a aderência às realidades práticas, revelando a experiência de quem conhece o Direito por dentro, através de contínuo tirocínio profissional.

Entra êle de chôfre no assunto, enquadrando a matéria no estrito campo dogmático-jurídico, sem tergiversações e delongas, com apôio na tradição da literatura jurídica pátria, posta em permanente confronto com os mais ilustres comercialistas alienígenas, não só da França e da Itália, mas também da Inglaterra e da Alemanha, demonstrando não ter ficado jungido às fontes latinas. Essas qualidades revelam-se sobretudo no seu estudo sôbre a posição jurídica do debenturista em face da falência, onde não se perde em generalidades, limitando-se a debater as teses relacionadas com o tema proposto. Trata-se, aliás, de sua melhor contribuição à Jurisprudência nacional, denotando a sua

1. San Tiago Dantas - Prefácio ao "Parecer Jurídico" de RuI Barbosa sôbre o Projeto de Código Civil (Obras Completas, de RUI, Vol. XXXIII, 1905, t. III, pág. XII).

2. Foram êstes os temas versados no concurso: a) Da posição juridica do debenturista em face da falência (173 págs.); b) Os sócios de responsabilidade illimitada de uma sociedade mercantil são comerciantes? (53 págs.); c) Da hipoteca naval no Brasil (52 págs.). 
predileção pelos problemas pertinentes aos títulos de crédito, a cujo estudo iria dedicar a sua derradeira obra.

As análises que, nesse campo, foram realizadas por Octavio Mendes conservam ainda atualidade doutrinária e prática, o que não passou despercebido ao insígne comercialista Tullio Ascarelli, que, mais de uma vez, se reporta à opinião do mestre campineiro, em sua primorosa Teoria Geral sôbre Títulos de Crédito. ${ }^{3}$

Formado sob a influência da chamada "Escola científica do Direito", isto é, daquela corrente que, sobretudo por obra de positivistas italianos, conciliava os ensinamentos de H. Spencer e de A. Comte numa compreensão objetiva da experiência jurídica, Octavio Mendes, mais uma vez, afirma a necessidade de atender às exigências econômicas, que antecedem e determinam os institutos jurídicos, os quais, consoante palavras de Vivante, por êle invocadas, não podem ser elaboradas como "construções geométricas".

Numa atitude pragmática, pondera que, em matéria como esta dos títulos ao portador, é impossivel legislar com proveito, mantendo sempre inteiro acôrdo entre as necessidades práticas e os princípios de doutrina. ${ }^{4}$

3. Cf. Ascareuli - op. cit., trad. de Nicolau Nazo, São Paulo, 1943. O ilustre comercialista peninsular refere-se a Octavio Mendes, entre outras, às págs. 214, 259, 262, 267, 289, 309, 338, 390, etc. À pág. 338, n. 1, pondera ASCARELLI, referindo-se ao problema do fundamento do "Direito cartular": "No direito brasileiro é interessante observar a posição de Octavio Mendes (Títulos de Crédito, São Paulo, 1931), que adere às teorias contratualistas (coerentemente, aliás, com a sua adesão à tese da causalidade da declaração cambiária) mas ao mesmo tempo afirma, coerente com o art. 1.506 do Código Civil, que a emissão pode ser involuntária (Cf. também págs. 5, 11 e 286 do Direito Comercial Terrestre do mesmo Autor)."

Essa posição de OCTAVIo Mendes, apontada por AscaremLI, traduz bem a sua linha de pensamento, de fidelidade às teorias tradicionais, ajustando-as aos imperativos das normas vigentes.

4. Cf. Octavio Mendes - "A posição jurídica do debenturista", em Ensáios do Direito Comercial, São Paulo, 1920, pág. 40. Também em sua monografia Dos Títulos de Crédito, cit., pág. 128, reitera que 
Preocupa-o a multiplicidade das teorias que, consoante frase incisiva de Thaller, que êle cita e acolhe, "tem dado mais fadiga ao cérebro humano, do que resultados satisfatórios", mas isto não o impede de expôr e debater as lições de Thaller, de Kuntze, de Brunner, de Siegel, de Bruschettini ou de Saleilles, assim como de trazer, a todo instante, à colação as teses dos comercialistas nacionais, como Inglez de Sousa, Carvalho de Mendonça, Margarino Torres e Pontes de Miranda.

Essa desconfiança teorética levava-o, às vêzes, a apegarse em demasia às chamadas doutrinas tradicionais, como, por exemplo, o fêz ao se opôr, intransigentemente, à já triunfante teoria sôbre a unilateralidade do ato em que se assenta a constituição do direito cartular. ${ }^{5} \mathrm{O}$ empirismo de Octavio Mendes impedia-o de reconhecer que, pelas exigências mesmas da vida econômica que condicionam as normas comerciais, a teoria unilateral não era "uma audácia" passageira, mas antes uma linha necessária no desenvolvimento da Ciência jurídica. ${ }^{6}$

Outras vêzes, porém, essa tendência conservadora prevenia-o contra a introdução no Direito pátrio de doutrinas correspondentes a outras circunstâncias sócio-econômicas, criticando o legislador brasileiro, por copiar ou adaptar leis estrangeiras sem levar em conta a especificidade de nossa estrutura econômica, incipiente, onde o crédito obedece, então como agora, a taxas de juros desusadas na Europa e nos Estados Unidos da América.

\footnotetext{
"os verdadeiros interêsses sociais nem sempre se harmonizam com os princípios jurídicos", o que revela bem a sua compreensão estática e abstrata dos valôres da Jurisprudência.

5. Op. cit., pág. 43 e segs. Octavio Mendes sempre se manteve fiel à teoria contratual, insistindo sempre na sua tese de que "unilateralidade e relação jurídica são termos que se repelem” (Cf. Dos Títulos de Crédito, págs. 92 e segs.).
}

6. Op. cit., pág. 172. 
Podemos, aliás, divergir de suas teses, mas não há como reconhecer a coerência de seu pensamento, o amor às suas convições, que o levam, às vêzes, a assumir um tom polêmico.

Exemplo dessa sua atitude polêmica têmo-la nas críticas movidas a Pontes de Miranda, jurisconsulto pertencente à geração posterior, bem mais sensível aos valôres das teorias gerais, e pessoalmente propenso à aceitação de idéias novas nos domínios da Jurisprudência.

Insurge-se Octavio Mendes especialmente contra a tese expendida por Pontes de Miranda em sua obra Dos Títulos ao Portador, pág. 274, de que "é a posse e não a propriedade que produz o direito cartular". O professor paulista, ao contrário, sustenta diretriz diferente, exigindo o título de propriedade, sem o qual, obtempera êle, não há que falar em exercício de direito cartular. Referindo-se a essa divergência, no Direito brasileiro, Ascarelli prefere a "teoria da propriedade", seguida por Octavio Mendes."

Fazendo ironia sôbre as conhecidas tendências germanófilas de Pontes de Mrranda nos domínios do Direito, repele a sua pretensão de criar, com base no art. 521 do Código Civil, "uma ação de reivindicação de posse, expediente alemão, que a ciência moderna muito terá de aplaudir, e a sociedade de agradecer à inventiva costumeira e filosófica dos alemães", Octavio Mendes procura pôr em evidência os méritos da teoria da propriedade, em confronto com a da posse, para legitimidade da titularidade do direito cartular e conclui, desconsoladamente:

"Em artigo que publicamos na Revista de Direito, vol. 60, pág. 206-233, impugnamos integralmente essa opinião de Pontes de Muranda.

Esse artigo foi publicado em Março de 1921.

Estamos em 1930. Há nove anos que impugnamos a opinião de Pontes de Miranda, e durante todo

7. ASCARElli - Teoria Geral, cit., pág. 267. 
êsse lapso de tempo mantivemos sempre a nossa impugnativa, contra a qual não vimos ainda resposta satisfatória."

No Tomo XXXIII de seu Tratado de Direito Privado, Pontes de Miranda repete o que dissera em seu livro de 1921, e sem se referir às criticas feitas por Octavio Mendes à sua posição, procura dar o rigoroso sentido de sua interpretação ao art. 521 do Código Civil, o qual, a seu ver, "separa-nos de outros povos", por conter "uma vindicatória de posse", que não se confunde nem com a reivindicação, nem com a reintegração de posse. ${ }^{9}$

Os toques polêmicos não constituem, todavia, a nota dominante nas páginas do catedrático das Arcadas, cujo estilo é em geral claro, sóbrio e comedido, revelando grandes qualidades de exposição, como se pode apreciar, por exemplo, ao condensar as lições de Brunner, de SiEger, ou de Bruschettini. Uma nota de alta probidade intelectual distingue os seus estudos, timbrando em assinalar a fonte em que baseia as explanações feitas, como se vê no fim dos capítulos XVIII, XXII e XXIII, usando, modestamente, de expressões como estas: "tal é a lição que se vê em Brunner, sábio professor de Berlim, no seu precioso livro Werthpapieri, do qual extraimos o que deixamos dito". 10

Pois bem, é êsse alto sentido de responsabilidade que se observa no seu Direito Comercial Terrestre, que é o compêndio de suas lições na Faculdade do Largo de São Francisco. É uma obra que ainda hoje se lê com proveito, refletindo a repercussão no Brasil da Dogmática Jurídica

8. Octavio Mendes - Dos Títulos de Crédito, cit., pág. 121, Cfr. também as críticas feitas por êle à teoria de Pontes DE Miranda, de que no título ao portador não há um direito de crêdito, mas uma "pré-forma" dêsse direito. (Capítulo XIV).

9. Cf. Pontes De MIRANdA - Tratado, cit., vol. XXXIII, págs. 138 e segs.

10. Dos Títulos de Crédito, cit., pág. 170. 
conceitual européia, sob a inspiração da Escola de Exegese e dos Pandectistas, ainda numa fase de transição para uma visão mais compreensiva das relações privadas, que, no caso especial do Direito italiano, veio adquirir expressão própria com o desenvolvimento da grande Escola de Scialoja e de Vivante, e, na Alemanha, ofereceu os seus melhores frutos com a Jurisprudência dos Interêsses.

0 seu compêndio confirma os seus dotes de seriedade e clareza, só surgindo, vez por outra, uma pitada de ironia, como na referência à inutilidade da matrícula dos comerciantes, cuja única vantagem era conferir as honras de capitão da guarda nacional, impedindo fôssem recolhidos à enxovia, quando processados criminalmente. Era essa, sublinhava o professor, a razão pela qual muitos negociantes, em véspera de falência, se faziam matricular...

Bem característica é, pelo exposto, a posição de Octavio Mendes na história das idéias jurídico-mercantis no Brasil. Situa-se êle na corrente da Jurisprudência conceitual, assinalando um momento significativo na formação de nosso Direito cartular, figurando os seus escritos condignamente ao lado de trabalhos de ilustres monografistas dedicados ao problema dos títulos de crédito, como Saraiva, Paulo Maria de Lacerda, Margarino Torres, Whitaker e Pontes de MiranDA, que vieram progressivamente alargando a participação do pensamento brasileiro na renovação do Direito Comercial. ${ }^{11}$

11. Essa renovação foi, às vêzes, entendida, e a meu ver errôneamente, no sentido da crescente comercialização do Direito Civil. OctAvio Mendes, que de início compartilhava da tese de THALler sôbre a evolução do Direito Privado, "pela subordinação do Direito Comercial ao Direito Civil, em todos os assuntos regulados por êste", por ser o Direito Geral, (Ensáios de Direito Comercial, cit., pág. 156) acabou se enfileirando entre os partidários da tese da "absorção do Direito Civil pelo Direito Comercial" (Direito Comercial Terrestre, cit., pág. 108). Trata-se, a bem ver, de duas teses contrapostas e abstratas, ambas sem correspondência com a experiência jurídica de nosso tempo, pois, por mais que se tenha dado e se dê a convergência dos dois Direitos no plano dos princípios e normas gerais, nem por isto desaparecem as peculiaridades resultantes de exigências inerentes às atividades mercantis e industriais. 